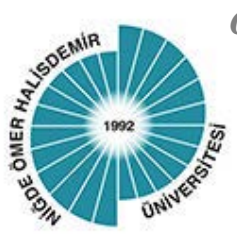

Ömer Halisdemir Üniversitesi İktisadi ve İdari Bilimler Fakültesi Dergisi

Yll: 2021 Cilt-Sayl: 14(4) ss: 1328-1339

Academic Review of Economics and Administrative Sciences

Year: 2021 Vol-Issue: 14(4) pp: 1328-1339

http://dergipark.org/tr/pub/ohuiibf/
Araştırma Makalesi

Research Article
ISSN: 2564-6931

DOI: $10.25287 /$ huiibf. 868753 Geliş Tarihi / Received: 27.01.2021 Kabul Tarihi / Accepted:14.09.2021 Yayın Tarihi / Published: 15.10.2021

\title{
Hierarchical Clustering Of Selected Countries According To The Variables Of Population, National Income And Exports Of Goods And Services
}

\author{
Seyyid Ali ERTAŞ \\ Mehmet BATI ${ }^{(1) 2}$
}

\begin{abstract}
The changes in the population, gross domestic product (GDP) and exports of goods and services of the 32 countries that we have selected for 25 years have annually been examined. In this study, we use hierarchical structure methods such as minimum spanning tree (MST) and hierarchical tree (HT) to explain the relationship between countries' GDP, population, and annual changes in exports of goods and services from 1991 to 2016. Using MST and HT, we obtained the countries with the same economic development level as some variables. At the same time, we obtained the opportunity to see which country's population, GDP, and annual changes in exports of goods and services are at a similar change. Finally, for observing the cluster structure, we use a clustering linkage procedure. This topology will provide us with a useful guide to understanding their behavior and identifying the dominant associated countries in the network as part of a complicated network.
\end{abstract}

Keywords : Hierarchical clustering, Minimum spanning tree, Hierarchical tree, Population, Gross domestic product, Exports.

Jel Classification $\quad: C 38, P 23, B 27,057$

\footnotetext{
${ }^{1}$ Öğr. Gör. Dr., Yozgat Bozok Üniversitesi, Yerköy Adalet MYO, seyyidali.ertas@bozok.edu.tr, ORCID 0000-0003-2050-1956.

${ }^{2}$ Doç. Dr., Recep Tayyip Erdoğan Üniversitesi, Fen Edebiyat Fakültesi, Fizik, mehmet.bati@erdogan.edu.tr, ORCID 0000-0003-2304-4869. 


\title{
Seçilmiş Ülkelerín Nüfus, Gsyih, Mal Ve Hizmetlerín İHRACATI DEĞİŞKENLERINNE Göre HIYYERARŞIK KÜMELENMESİ
}

\begin{abstract}
$\ddot{O} z$
Bu çalışmada, 32 ülkenin 25 yıllık; nüfus, gayri safi yurtiçi hasıla (GSYIH) ve mal ve hizmet ihracatındaki değişimleri arasındaki ilişkiler yıllık olarak incelenmektedir. 1991-2016 yılları arasında ülkelerin GSYİH, nüfus ve mal ve hizmet ihracatındaki yıllık değişimler arasındaki ilişkiyi açıklamak için minimum örten ă̆aç (MST) ve hiyerarşik ağaç (HT) gibi hiyerarşik yapı yöntemleri kullanılmıştır. MST ve HT'yi kullanarak, bazı değişkenlerle aynı ekonomik kalkınma düzeyine sahip ülkeleri elde ettik. Aynı zamanda, hangi ülkenin nüfusunun, GSYIH'sının ve mal ve hizmet ihracatındaki yıllık değiş̧ikliklerin benzer değişime sahip olduğunu görme firsatı da elde ettik. Son olarak, küme yapısını gözlemlemek için kümeleme yöntemlerini kullandık. Bu topoloji, bize değişkenlerin davranışlarını anlamak ve karmaşık bir ă̆ın parçası olarak ăgdaki baskın ilişkili ülkeleri tanımlamak için yararlı bir kılavuz sağlamaktadır.
\end{abstract} Anahtar Kelimeler
yurtiçi hasıla.

Jel Sinıflandırmasi $\quad$ : C38, P23, B27, 057

\section{INTRODUCTION}

In the past two decades, the application of statistical physics to economic and social data has attracted great attention (Galam, 2008: 19; Górski, Kwapień, Oświęcimka, Drożdż, 2008: 114; Mantegna, 2000; Naylora, Roseb, Moyle, 2007: 382; Onnela, Chakraborti, Kaski, Kertesz, Kanto, 2003: 68). Currently, research on financial networks mainly focuses on network features based on the hierarchical tree (HT) and the minimum spanning tree (MST) graph (Feng \& Wang, 2010: 21; Galam, 2008: 19; Górski et al., 2008: 114; Jang, Lee, Chang, 2011: 390; Keskin, Deviren, Kocakaplan 2011: 390; McDonald, Suleman, Williams, Howison, Johnson 2005: 72; Naylora et al., 2007; Nie, Song, Li, 2016: 444; Onnela et al., 2003; Rešovský, Horváth, Gazda, Siničáková, 2013: 21; Wu \& Zheng, 2013: 8). The MST on correlation networks has become an indispensable tool in network analysis to filter the most important information and provide a meaningful taxonomy (Sharif, Yusoff, Djauhari 2012: 6; Mizuno, Takayasu, Takayasu, 2006: 364).

The MST problem dates back to Boruvka's algorithm which is the first efficient solution to find MST in 1926 and it is among the earliest algorithms for combinatorial optimization problems (Graham \& Hell, 1985:7). The solution of the MST algorithm problem was developed by Kruskal (1956: 7), Prim (1957: 36), Dijkstra (1959: 1), and Sollin (1965). Now, Prim's and Kruskal's algorithms are two commonly used algorithms that can be used to find the MST. Network analysis has been developed using the MST. Where exchange dynamics such as effective and dependent currency structures can be found in MSTs have shown by McDonald et al. (2005). The MST has been extensively used not only in financial work but also by Bakkalbasi and Krichel (2006: 43), who use it in sociology, Park and Yilmaz (2010) in transportation, Gower and Ross (1969: 18) in Cluster Analysis, Situngkir (2004) in politics and Sneath (1957: 17) in Taxonomy. Eom et al., for its application to filter the information contained in a correlation matrix (Eom, Oh, Kim, 2008: 53). MST has been used for the analysis of the relationship between CO2 emission and development level (Deviren \& Deviren, 2016: 451). MST analyses have been applied to find the history of the transference of the hepatitis C virus by Spada and co-workers (Spada et al., 2004). 
Ertaş, S. A., \& Batı, M. (2021). Hierarchical clustering of selected countries according to the variables of population, national income and exports of goods and services. Ömer Halisdemir Üniversitesi Íktisadi ve İdari Bilimler Fakültesi Dergisi, 14(4), 1328-1339.

In most of the above studies, HTs were presented alongside the MST (Mizuno et al., 2006; Naylora et al., 2007). As Mizuno and his colleagues (Mizuno et al., 2006) analyzed data from various currencies in the foreign exchange market hierarchical classification of units which are the big ones that are driving the world foreign exchange market. Feng and coworkers have studied the structural evolution of an Asian network using daily exchange rate data with HT and MST (Feng et al., 2010). Kantar (2013: 392) studied the topological between GDP, emissions, and electricity consumption by using HT and MST. Mantegna has investigated the hierarchical arrangement of stocks traded in a financial market using HT and MST by investigating the daily change logarithm of stock prices (Mantegna, 1999: 11). Hierarchical clustering of the foreign exchange market has been studied using HT and MST (Wu et al., 2013). Yan and coworkers have applied HT based regression to examine the train-vehicle crash estimates at passive highway-rail grade crossings (Yan, Richards, Su, 2010: 42). Hierarchical clustering was first used for the disease of depression in the study of $\mathrm{Li}$ ( $\mathrm{Li}$ et al., 2017).

Development is any growth in the quality of life of people in a certain country that is measured with indicators of development. There are many world development indicators. Such as population dynamics, education, labor, health, agriculture, climate change, energy, biodiversity, economic structure, income, trade, labor productivity, business, stock markets, military, communications, transport, technology, trade, dependency, refugee, tourism, migration, etc. (World Bank, 2021).

There are many countries in the world that we can call advanced and developing, namely hardcore and peripheral countries. Central countries are developed countries in terms of socio-economic variables according to the peripheral countries. The difference in economic development between countries is due to GDP, health indicators, population, and demographic factors. We used population chance, GDP, and goods and services exports indicators using hierarchical clustering and minimal spanning tree methods to determine the relationship between countries' levels of development. The growth in real GDP per capita indicates the pace of income growth per head of the population. As a single composite indicator, GDP is the foundation of economic growth and constitutes one of the most important infrastructure inputs in economic development. In many articles, population and GDP are examined together (Wesley \& Peterson, 2017: 11; Heady \& Hodge, 2009: 35). Wesley (2017: 11) has drawn on historical data to chart the links between population growth, growth in per capita output, and overall economic growth over the past 200 years.

The aim of the article is to show that some countries are similar or different from each other in terms of economic development according to population, GDP, and export of goods and services. The importance of working is that we have the opportunity to see similarities and differences in terms of the economic development between countries in different geographies using MST and HT. MST and HT are new methods for social sciences. It is frequently used in many fields to classify complex information. We believe that the application of such different methods to social areas will also be beneficial in terms of method diversity.

The structure of the paper is as follows. The next section gives the methods, Section 3 shows the results and discussion, and Section 4 presents the conclusion.

\section{METHODS}

In this section, we give a concise description of the methodology. In our research, we use the methodology of (Mantegna et al., 2000) using MST and HT. First, let $T_{i}(t)$ be the annual exchange rate of $i$ th country data at time $t$ (where $i=1,2, \ldots, 32$ ). To construct networks, we calculate the logarithmic rate of chance $R_{i}(t)$ defined as

$$
R_{i}(t)=\ln \left(T_{i}(t)\right)-\ln \left(T_{i}(t-1)\right)
$$


Ertaş, S. A., \& Batı, M. (2021). Hierarchical clustering of selected countries according to the variables of population, national income and exports of goods and services. Ömer Halisdemir Üniversitesi Íktisadi ve İdari Bilimler Fakültesi Dergisi, 14(4), 1328-1339. equation

Definition of Pearson correlation coefficients between $i$ and $j$ country is given by the following

$$
C_{i j}=\frac{\left\langle R_{i} R_{j}\right\rangle-\left\langle R_{i}\right\rangle\left\langle R_{j}\right\rangle}{\sigma_{i} \sigma_{j}}
$$

where $\sigma$ is standard deviation $\sigma_{i}=\sqrt{\left\langle R_{i}^{2}\right\rangle-\left\langle R_{i}\right\rangle^{2}}$ and $\langle\cdots\rangle$ stands for the average over interested period. All the diagonal elements of correlation matrix $(C)$ are $C_{i i}=1$.

To create the MST and HT, we start by transforming the correlation matrix $C$ into a distance matrix $(D)$. We use transformation below

$$
D_{i j}=\sqrt{2\left(1-C_{i j}\right)}
$$

$D$ matrix is symmetric $\left(D_{i j}=D_{j i}\right)$ and has zero diagonal values. Since $-1 \leq C_{i j} \leq 1$, we have $0 \leq D_{i j} \leq 2$. This distance matrix $D$ can be thought to represent a fully connected graph with edge weights $D_{i j}$ (Cormen, Leiserson, Rivest, Stein 2009; West, 1996). The distances satisfy the following three axioms of Euclidean distance: I) $D_{i j}=0$ if $(i=j)$ II) $D_{i j}=D_{j i}$ III) $D_{i j} \leq D_{i k}+$ $D_{k j}$.

The small values of $D_{i j}$ mean the high correlations. The MST is a theoretical concept of graph theory. It serves as the issue to derive the MST connected distance weighted graph (smaller distance values define higher correlation values). The most frequently used algorithms to identify MST are Kruskal's, Prim's, and Boruvka's algorithms.

Hierarchical trees are derived from Euclidean distance to get more information about links and mainly about clustering in the system. We also use HT that one may detect the different clusters of countries according to their geographical location and commercial growth more clearly. Since Kantar has presented the procedure of obtaining HT (Kantar et al, 2013) in detail, Here we will briefly summarize.

We want to determine the subdominant ultrametric distance matrix $D_{i j}^{\wedge}$ for build the respective HT as define by Mantegna (Mantegna, 1999). The distance $D_{i j}$ between the countries of $i$ and $j$ is found as a maximal value of any Euclidean distance obtained by moving in single steps from the starting country to the ending country over the shortest part of the MST connecting the two countries and written as $D_{i j}^{\wedge} \leq \max \left\{D_{i k}, D_{k j}\right\}$ (Deviren et al., 2016). Numerous hierarchical clustering methods can be found in the literature (Anderberg, 1973). In this paper, we use average linkage cluster analysis (ALCA).

MST and HT method is adaptable and effective to many situations frequently used in the literature. For this reason, this method is preferred and used in most disciplines (physics, economics, etc.). All data have been stored and transferred to a PC for analysis using a computer program. Calculations have been performed by using self-written scripts in addition to available package programs in MATLAB. These applications are also available in most clustering software packages. We have calculated the correlation and distance matrices and using these data, we have been drawn MST (Graphminspantree, 2021) and HTs (Dendrogram, 2021) according to the desired algorithm through package programs in MATLAB. 
Ertaş, S. A., \& Batı, M. (2021). Hierarchical clustering of selected countries according to the variables of population, national income and exports of goods and services. Ömer Halisdemir Üniversitesi Íktisadi ve İdari Bilimler Fakültesi Dergisi, 14(4), 1328-1339.

\section{RESULTS AND DISCUSSION}

All data used in the article are taken from World Development Indicators (WDI) (World Bank database), and available online (http://data.worldbank.org/). It gives the most present and true global development data available and covers domestic, local, and global evaluations. In this study, we select 32 countries which abbreviations are represented in Table 1.

We conducted HT and MST analyses for population, GDP, and export of goods and services for the years between 1991 and 2016 and for 32 countries. As a result of analysis, we obtained both HT and MST shapes for each variable.

In order to investigate the population changing rate relation between selected countries. We plot Fig. 1 and Fig. 2. As a result of the HT analysis conducted to determine the countries in which the annual population changes for the years between 1991 and 2016 and for 32 countries differed in which countries. The algorithm for calculating the distance between clusters determines the number of clusters. In this study, ALCA method was used and triple clusters were obtained in HTs. The countries were collected in the three-color group (See Fig. 1). Countries in the red group are similar in terms of commercial development according to the annual population changing rate. The countries in the blue group show similar characteristics to each other according to the annual population changes and they are in the same cluster. The countries in the green group are in the same cluster again. In other words, they show similar characteristics to each other according to the change in population rate. The important point here is that in the last stage the green country group forms a single cluster group with blue and red country groups. Looking at the clusters, it is seen that African countries form groups among themselves and European countries form groups among themselves. It can be concluded that there is a geographical and cultural effect in population changes. These results are consistent with studies in the literature (Castelli, 2018: 25; de Haas et al., 2019: 45; IOM, 2020). In addition, it is seen that countries with similar population changes are countries with similar development levels.

Table 1. Countries and Their Abbreviations

\begin{tabular}{|c|c|c|c|}
\hline Countries & Abbreviations & Countries & Abbreviations \\
\hline Angola & ANG & Argentina & ARG \\
\hline Cameroon & CMR & Canada & CAN \\
\hline Egypt & EGY & Ethiopia & ETH \\
\hline European Union & EUR & France & FRA \\
\hline Germany & DEU & Ghana & GHN \\
\hline India & IND & Indonesia & IDN \\
\hline Mexico & MEX & Nigeria & NGR \\
\hline Norway & NOR & Pakistan & PAK \\
\hline Poland & POL & Russia & RUS \\
\hline Saudi Arabia & SAU & South Africa & $\mathrm{ZAF}$ \\
\hline Sweden & SWE & The United Kingdom & GBR \\
\hline The United States of America & USA & Turkey & TUR \\
\hline
\end{tabular}


Ertaş, S. A., \& Batı, M. (2021). Hierarchical clustering of selected countries according to the variables of population, national income and exports of goods and services. Ömer Halisdemir Üniversitesi İktisadi ve İdari Bilimler Fakültesi Dergisi, 14(4), 1328-1339.

We see that in Fig. 2. according to the results of the minimum spanning tree, 7 central countries were obtained. These central countries are IND, CMR, IDN, EGY, ANG, SAU, and GBR. The distance between the countries in this nucleus and the other countries is short, and the countries that are gathered around this center constitute the periphery countries. For example, IND is the central country, and BRA, JPN and the USA are the neighboring countries and the distance between them is rather short. That is, these countries have similar characteristics in terms of change of population in each other. In the same way, CMR, ETH, ARG, CHN, and MEX are the closest to each other. USA and CHN are linking these two groups. In these grouped countries population changes are similar according to MST results.

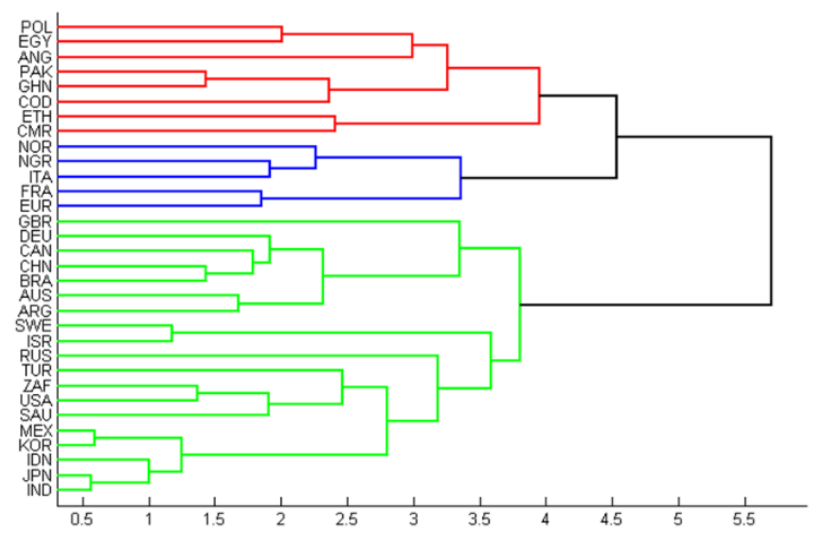

Figure 1. Hierarchical Tree of Selected Countries For Population Change Over The Period of 1991-2016.

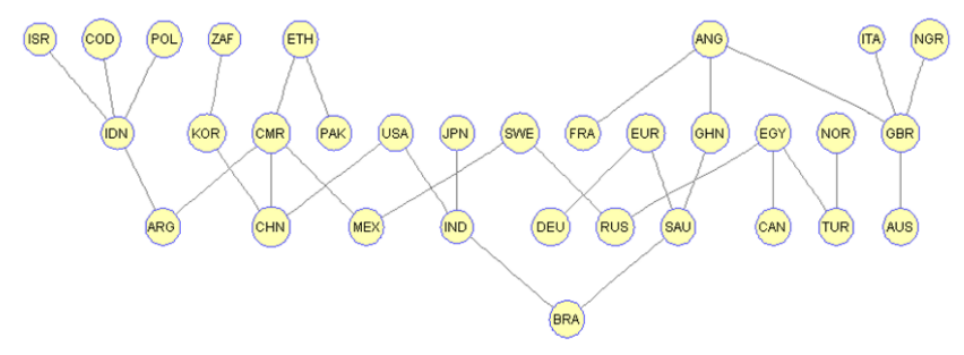

Figure 2. Minimum Spanning Tree of The Selected Countries Population Change Over The Period 1991-2016.

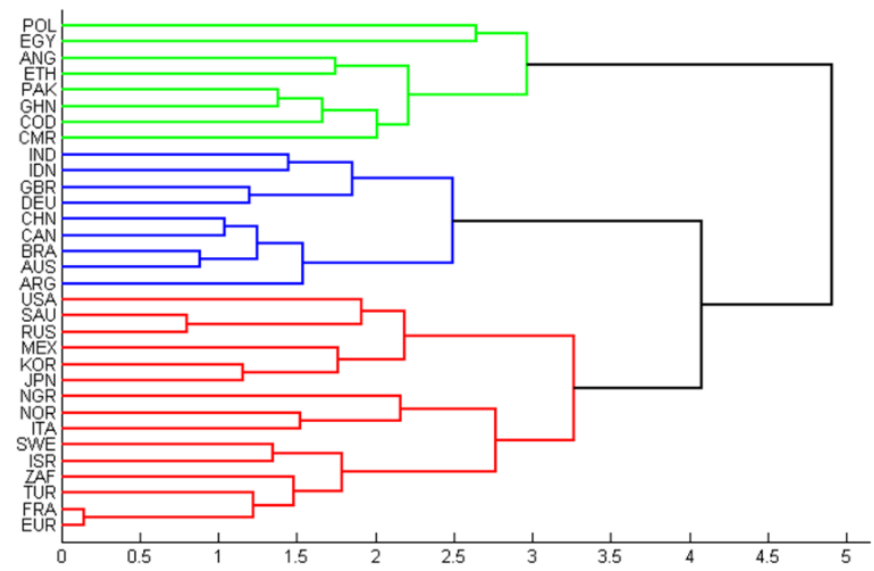

Figure 3. Hierarchical tree of the countries for GDP change over the period of 1991-2016. 
Ertaş, S. A., \& Batı, M. (2021). Hierarchical clustering of selected countries according to the variables of population, national income and exports of goods and services. Ömer Halisdemir Üniversitesi İktisadi ve İdari Bilimler Fakültesi Dergisi, 14(4), 1328-1339.

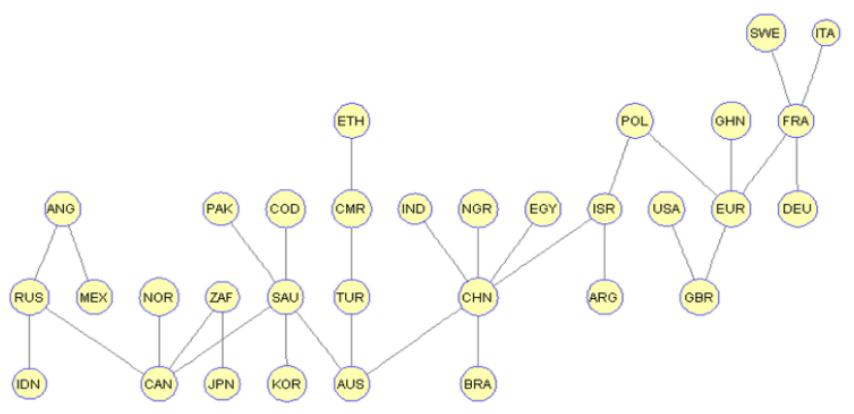

Figure 4. Minimum spanning tree of the country's GDP change over the period 1991-2016.

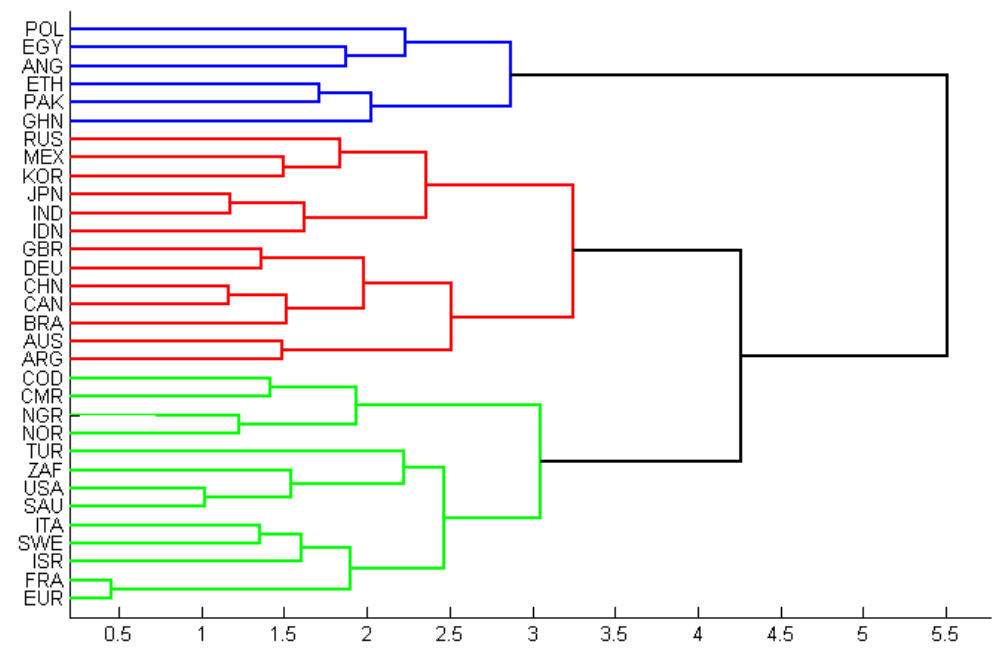

Figure 5. Hierarchical tree of the 32 countries for exports of goods and services change over the period of 1991-2016.

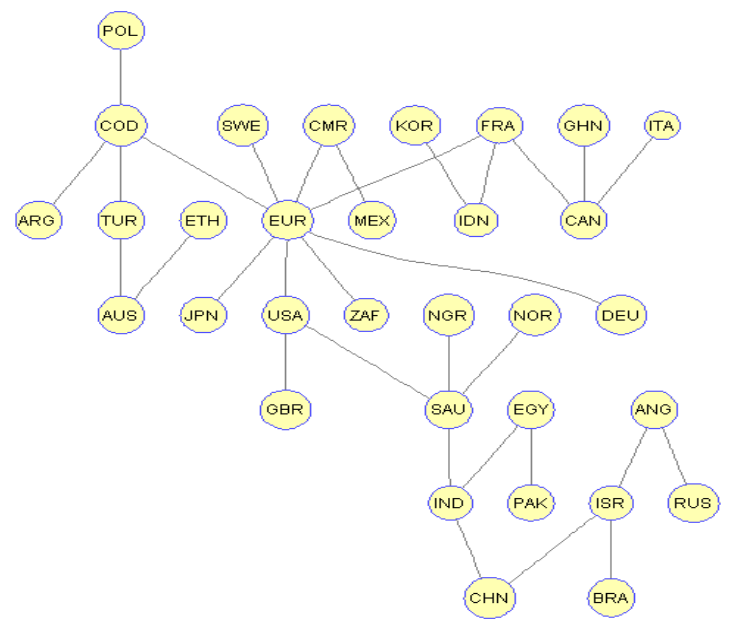

Figure 6. Minimum spanning tree of the 32 countries exports of goods change over the period 1991-2016 
Ertaş, S. A., \& Batı, M. (2021). Hierarchical clustering of selected countries according to the variables of population, national income and exports of goods and services. Ömer Halisdemir Üniversitesi Íktisadi ve İdari Bilimler Fakültesi Dergisi, 14(4), 1328-1339.

To analyze the relationship between the GDPs of the countries, we plot HT in Fig. 3 and MST in Fig. 4. According to Fig. 3, POL, EGY, ANG, ETH, PAK, GHN, COD, and CMR are in the green group. USA, SAU, RUS, MEX, KOR, JPN, NGR, NOR, ITA, SWE, ISR, ZAF, TUR, FRA, and EUR are in the red group. In addition, IND, IDN, GBR, DEU, CHN, CAN, BRA, AUS, and ARG are in the blue group. That is, countries in the red, blue, and green groups are similar countries in terms of development relative to annual GDP changes among themselves. The red cluster and the blue cluster form a second stage group. At last, this group brings them into a green group, bringing them to a new group. Again, it is seen that developed countries are in the same group in terms of annual GDP changes.

In Fig. 4, the distance lines between countries show similarities or differences in terms of development levels relative to annual GDP changes. According to the results of the minimum spanning tree, even central countries were obtained. Some of these central countries are RUS, CAN, SAU, AUS, CHN, ISR, EUR, and FRA. We see that the network of countries is divided into three defined sets. EUR and FRA are the central countries and the USA, GBR, POL, GHN, SWE, ITA, DEU linking these central countries. Development levels of these countries are very similar. These groups have a high income except GHN. CHN centered group IND, NGR, EGY, and BRA have middle income. Other groups are mixed according to the development level. When the results of HT and MST are examined, there is not much difference in the groupings. Countries that are in the same group in HT are generally seen to have close ties to each other in MST. The reason for the difference in some groupings is the algorithms used in clustering analysis.

Many investigators accept that high-income countries' economic growth is likely to be relatively slow in the coming years in part because population growth in these countries is predicted to slow significantly (Baker, Delong, Krugman, 2005). Others argue that population growth has been and will continue to be problematic as more people naturally use more of the finite resources available on earth, as a result of that decreasing long-term potential growth (Linden, 2017)

Finally, we investigate exports of annual goods and services in selected countries. We see that from Fig. 5, POL, EGY, ANG, ETH, PAK, and GHN are similar countries according to the changes in exports of annual goods and services, and these countries constitute the blue group In addition, it is located in the green group of COD, CMR, NGR, NOR, TUR, ZAF, USA, SAU, ITA, SWE, ISR, FRA, EUR and RUS, MEX, KOR, JPN, IND, IND, GBR, DEU, CHN, CAN, BRA, AUS, ARG are in the red group and are similar countries in terms of development according to annual changes in exports of goods and services.

According to the results of the minimum spanning tree in Fig.6, EUR, SAU, COD have four and more links. ISR, IND, USA, CAN, FRA has three links. The biggest group is the EUR-centered group which includes SWE, CMR, MEX, COD, USA, JPN, ZAF, and FRA. They are similar countries in terms of development relative to annual changes in exports of goods and services. If to summarize, it is seen that developed high-income countries are in the same groups, and middle-income countries form groups among themselves. It is not possible to use a single indicator to determine the entire development level of a country. More holistic analyzes can be made using a combination of indicators in the form of indexes. However, our aim here is to try to understand the relations between countries according to individual indicators.

It should also be noted that the disadvantages of hierarchical clustering are that the results of the MST and HT methods are not fully coherent, with each other, the reason this, how many subsets to use is often optional, there are several hierarchical clustering gauges (average linkage, single linkage, ward technique, etc.), and some procedures do not give unique solutions (Wasserman, 1994). 
Ertaş, S. A., \& Batı, M. (2021). Hierarchical clustering of selected countries according to the variables of population, national income and exports of goods and services. Ömer Halisdemir Üniversitesi Íktisadi ve İdari Bilimler Fakültesi Dergisi, 14(4), 1328-1339.

\section{CONCLUSION}

In this study, we have been investigated the strong relationship between the population national income of 32 countries selected using the MST and HT method for the period 1991-2016 and the variables of exports of goods and services. In the results of HT analysis conducted according to the annual population changes, the countries were gathered in three groups as red, blue, and green. The countries in the group of countries have similar characteristics in terms of economic development. In MST analysis results, countries were divided as central and peripheral. Other countries were gathered around the central countries, that is, they have similar characteristics with the central countries in terms of development. In our study, it is seen that European countries form groups among themselves. It is understood that geographical and cultural effects are important in annual population changes and GDP changes. We used three variables in our work. Analysis can be made with different variables in future studies on this subject. MST and HT are new methods for social sciences. It is frequently used in many fields to classify complex information. We believe that the application of such different methods to social areas will also be beneficial in terms of method diversity.

\section{REFERENCES}

Anderberg, M. R. (1973). Cluster analysis for applications. New York: Academic Press.

Baker, D., Delong, J., \& Krugman, P. (2005). Asset returns and economic growth. Brookings Papers on Economic Activity, (1), 289-315.

Bakkalbasi, N., \& Krichel, T. (2006). Patterns of research collaboration in a digital library for Economics, Proc. Am. Soc. Info. Sci. Tech., 43, 1550-8390.

Castelli, F. (2018). Drivers of migration: why do people move? Journal of Travel Medicine, 25, 1-7.

Cormen, T. H., Leiserson, C. E., Rivest, R. L., \& Stein, C. (2009). Introduction to algorithms. The MIT Press; 3rd edition Cambridge.

De Haas, H., Czaika, M., Flahaux, M. L., Mahendra, E., Natter, K., Vezzoli, S., \& Villares-Varela, M. (2019). International migration: Trends, determinants, and policy effects. Population and Development Review, 45, 885-922.

Dendrogram, (2021). Dendrogram Plot. $\quad$ Retrieved from https://www.mathworks.com/help/stats/dendrogram.html.

Deviren, S. A., \& Deviren. B. (2016). The relationship between carbon dioxide emission and economic growth: Hierarchical structure methods. Physica A, 451, 429-439.

Dijkstra, E. W. (1959). A note on the two problems in connection with graphs. Numer. Math, 1, 269.

Eom, C., Oh, G., \& Kim, S. (2008). Statistical investigation on connected structures of stock networks in a financial time series. J. Korean Phys. Soc., 53, 3837.

Feng, X., \& Wang, X. (2010). Evolutionary topology of a currency network in Asia. Int. J. Mod. Phys. $C, 21,471$.

Galam, S. (2008). Sociophysics: A review of Galam models. International Journal of Modern Physics $C, 19,409$.

Gower, J. C., \& Ross, G. J. S. (1969). Minimum spanning trees and single linkage cluster analysis. J. R. Stat. Soc. C, 18, 54.

Górski, A. Z., Kwapień, J., Oświęcimka, P., \& Drożdż, S. (2008). Minimal spanning tree graphs and power like scaling in FOREX networks. Acta. Phys. Pol. A, 114, 531. 
Ertaş, S. A., \& Batı, M. (2021). Hierarchical clustering of selected countries according to the variables of population, national income and exports of goods and services. Ömer Halisdemir Üniversitesi Íktisadi ve İdari Bilimler Fakültesi Dergisi, 14(4), 1328-1339.

Graham, R. L., \& Hell, P. (1985). On the history of the minimum spanning tree problem. IEEE Ann. Hist. Comput., 7, 43-57.

Graphminspantree, (2021). Graphminspantree Syntax. Retrieved from https://www.mathworks.com/help/bioinfo/ref/graphminspantree.html.

Heady, D. D., \& Hodge, A. (2009). The effect of population growth on economic growth: A metaregression analysis of the macroeconomic literature. Population and Development Review, 35, 221-248.

International Organization for Migration (IOM). (2020). World migration report 2020. Marie McAuliffe and Binod Khadria (eds.). Jawaharlal Nehru University.

Jang, W., Lee, J., \& Chang, W. (2011). Currency crises and the evolution of foreign exchange market: Evidence from minimum spanning tree. Physica A, 390, 707.

Kantar, E., \& Keskin, M. (2013). The relationships between electricity consumption and GDP in Asian countries, using hierarchical structure methods, Physica A, 392, 5678-5684.

Keskin, M., Deviren, B., \& Kocakaplan, Y. (2011). Topology of the correlation networks among major currencies using hierarchical structure methods. Physica A, 390, 719.

Kruskal, J. B. (1956). On the shortest spanning subtree of a graph and the traveling salesman problem, Proceedings of the American Mathematical Society, 7, 48.

Li, X. Jing, Z., Hu, B. Zhu, J., Zhong, N., Li, M., Ding, Z., Yang, J., Zhang, L., Feng, L., \& Majoe, D. (2017). A resting-state brain functional network study in MDD based on minimum spanning tree analysis and the hierarchical clustering, Complexity, 2017, 9514369. https://doi.org/10.1155/2017/9514369.

Linden, E. (2017, June). Remember the population bomb? It's still ticking. New York Times: Sunday Review, 4.

Mantegna, R. N. (1999). Hierarchical structure in financial markets. Eur. Phys. Jour. B, 11, 193.

Mantegna, R. N., \& Stanley, H. E. (2000). An introduction to econophysics: Correlations and complexity in finance. Cambridge: Cambridge University Press.

McDonald, M., Suleman, O., Williams, S., Howison, S., \& Johnson, N. F. (2005). Detecting a currency's dominance or dependence using foreign exchange network trees, Phys. Rev. E, 72, 046106.

Mizuno, T., Takayasu, H., \& Takayasu, M. (2006). Correlation networks among currencies, Physica A, $364,336-342$.

Naylora, M. J., Roseb, L. C., \& Moyle, B. J. (2007). Topology of foreign exchange markets using hierarchical structure methods. Physica A, 382, 199-208.

Nie, C. X., Song, F. T., \& Li S. P. (2016). Rényi indices of financial minimum spanning trees, Physica A, 444,883 .

Onnela, J. P., Chakraborti, A., Kaski, K., Kertesz, J., \& Kanto, A. (2003). Dynamics of market correlations: Taxonomy and portfolio analysis. Phys. Rev. E, 68, 056110.

Park, K., \& Y1lmaz, A. (2010). A social network analysis approach to analyze road networks. Paper presented at the ASPRS Annual Conference, San Diego, CA.

Prim, R. C. (1957). Shortest connection networks and some generalizations, Bell Labs Technical Journal, 36, 1389.

Rešovský, M., Horváth, D., Gazda, V., \& Siničáková, M. (2013). Minimum spanning tree application in the currency market. Biatec, 21, 21. 
Ertaş, S. A., \& Batı, M. (2021). Hierarchical clustering of selected countries according to the variables of population, national income and exports of goods and services. Ömer Halisdemir Üniversitesi İktisadi ve İdari Bilimler Fakültesi Dergisi, 14(4), 1328-1339.

Sharif, S., Yusoff, N. S., \& Djauhari, M. A. (2012). Network topology of foreign exchange rate. Modern Applied Science, 6, 35.

Situngkir, H. (2004). Hierarchical taxonomy in multi-party system. eprint arXiv:nlin/0405005.

Sneath, P. H. A. (1957). The application of computers to taxonomy. The Journal of General Microbiology, 17, 201.

Sollin, M. (1965) "Le tracé de canalisation". Programming, Games, and Transportation Networks (in French).

Spada, E., Saglioccca, L., Sourdis, J., Garbuglia, A.R., Poggi, V., Fusco, C. D., \& Mele A. (2004). Use of the minimum spanning tree model for molecular epidemiological investigation of a nosocomial outbreak of hepatitis c virus infection, Journal of Clinical Microbiology, 42, 42.

Wasserman, S. \& Faust K. (1994). Social network analysis methods and applications. Cambridge: Cambridge University Press.

Wesley, E., \& Peterson, F. (2017). The Role of population in economic growth. SAGE Open, 11, 1-15

West, D. B. (1996). Introduction to graph theory. ABD: Prentice-Hall.

World Bank, (2021). World Development Indicators. Retrieved from https://databank.worldbank.org/source/world-development-indicators.

Wu, X. Y., \& Zheng, Z. G. (2013). Hierarchical cluster-tendency analysis of the group structure in the foreign exchange market. Front. Phys., 8, 451-460.

Yan, X., Richards, S., \& Su, X. (2010) Using hierarchical tree-based regression model to predict trainvehicle crashes at passive highway-rail grade crossings, Accident Analysis \& Prevention, 42, 6474 
Ertaş, S. A., \& Batı, M. (2021). Hierarchical clustering of selected countries according to the variables of population, national income and exports of goods and services. Ömer Halisdemir Üniversitesi İktisadi ve İdari Bilimler Fakültesi Dergisi, 14(4), 1328-1339.

\section{Etik Beyanı}

: Bu çalışmanın tüm hazırlanma süreçlerinde etik kurallara uyulduğunu yazarlar beyan eder. Aksi bir durumun tespiti halinde ÖHய̈IİBF Dergisinin hiçbir sorumluluğu olmayıp, tüm sorumluluk çalışmanın yazarlarına aittir.

Yazar Katkıları : : 1.yazar, çalışmanın yazımında ve sonuçların yorumlanması aşamalarında katkı sağlamıştır. 2. yazar, çalışmada literatür taraması ve veri analizi ve program yazımı aşamalarında katkı sağlamıştır. 1. yazarın katkı oranı: \%50, 2. yazarın katkı oranı: \%50

Çıkar Beyanı : : Yazarlar arasında çıkar çatışması yoktur.

Ethics Statement $\quad$ : The authors declare that ethical rules are followed in all preparation processes of this study. In case of detection of a contrary situation, ÖHÜIIBF Journal does not have any responsibility and all responsibility belongs to the authors of the study

Author Contributions : The 1st author contributed to the writing of the study and the interpretation of the results. The second author contributed to the literature review and data analysis and program writing stages. 1 st author's contribution rate: $50 \%$, 2nd author's contribution rate: $50 \%$

Conflict of Interest $\quad$ : There is no conflict of interest between the authors. 